\title{
Çocukluk dönemi mutluluk ve huzur anılarının bilişsel şemalar ve psikolojik semptomlarla ilişkisi
}

\author{
The relationship between the memories of happiness and peace in \\ childhood with cognitive schemas and psychological symptoms
}

\begin{abstract}
Makale Geçmişi
Geliş : 27 Ekim 2018

Düzeltme : 17 Ocak 2019

Kabul : 13 Şubat 2019

Çevrimiçi : 10 Nisan 2019
\end{abstract}

\section{Makale Türü}

Araştırma Makalesi

\section{Article History}

Received : 27 October 2018

Revised : 17 January 2019

Accepted : 13 February 2019

Online : : 10 April 2019

Article Type

Research Article

\author{
Hasan Y1lmaz
}

\begin{abstract}
Öz: Yapılan pek çok araştırma, çocukluk çağı yaşantıları ile ileriki yaşlarda bireylerin kendi kendini kontrol, uyum ve problem davranışları arasında ilişkiyi konu almıştır. Bu anlamda, erken yaşlara ilişkin anılar, yetişkin yaşamında gözlenen psikolojik sorunlar için bir veri bankası niteliği taşımaktadır. Bu araştırmanın amacı, çocukluk dönemi mutluluk ve huzur anıları ile uyumsuz bilişsel şemalar ve psikolojik semptomlar arasındaki ilişkiyi ortaya koymaktır, Hangi şema alanının-boyutunun ve hangi psikolojik semptomun, çocukluk dönemi mutluluk ve huzur anıları ile daha yüksek bir ilişki içerdiği belirlemenin yanında yordama gücünü ortaya koymak hedeflenmiştir. Araştırmada ilişsisel tarama yöntemi kullanılmıştır. Bu amaçla, çocukluk dönemi mutluluk ve huzur anıları ölçeği, şema ölçeği ve kısa semptom tarama envanteri 468 kişilik üniversite öğrenci grubuna uygulanmış̧ır. Araştırmanın sonunda, aşırı tetikte olma - ketlenme, zedelenmiş otonomi, kopukluk-reddedilme şema alanlarının, ÇDMHA'nın en güçlü ve anlamlı yordayıcıları olduğu saptanmıştır. Bunun yanında psikolojik semptomlardan olumsuz benlik, somatizasyon ve depresyon belirtileri ile ÇDMHA arasında negatif yönde anlamlı ve yüksek korelasyon gözlenmiştir. Beş semptom birlikte, ÇDMHA puanlarına ilişkin toplam varyansın \%46'sını açılamaktadır. Araştırma bulgularından ebeveynlik eğitim programlarının hazırlanması ve geliştirilmesinde ve okullardaki önleyici ve geliştirici rehberlik hizmetlerinin etkililiğinin artırılmasında yararlanılabileceği önerilmektedir.
\end{abstract}

Anahtar Kelimeler: Çocukluk dönemi, Mutluluk ve huzur anıları, Bilişsel şemalar, Psikolojik semptomlar

Abstract: Many researches have focused on the relationship between childhood experiences and individuals' self-control, adaptation and problem behaviors at later ages. In this sense, memories of early ages have a data bank feature for the psychological problems observed in adult life. The aim of this research is to reveal relationship between incompatible cognitive schemes with happiness and peace memories in childhood and psychological symptoms, and also it is aimed to exhibit the predictive power along with determining which scheme field-aspect and which psychological symptom has higher relation with the happy and peace memories of the childhood period. Relational screening model was used in the research. For this purpose, childhood happiness and peace memories scale, schema scale and short symptom screening inventory were applied to 468 university students. At the end of the study, it was found that hypovigilance-inhibited, impaired autonomy, disconnection-rejection schema fields were the strongest and significant predictors of CHPM. Besides, negative and significant correlation was observed between negative self, one of psychological symptoms, and somatization symptoms. It explains 46 percent of total variance related to CHPM scores with the five symptoms. It has been suggested that research findings could be used to prepare and develop parenting education programs and to increase the effectiveness of preventive and developer guidance services in schools.

Keywords: Childhood, Memories of happiness and peace, Cognitive schemes, Psychological symptoms 


\section{SUMMARY}

\section{Introduction}

In the maturation period, the quality and content of early childhood life is the most important determinant of psychological health, healthy human relations, academic success and social cohesion in later ages (Nia, Sovani and Forooshani, 2014). In other words, childhood experiences are the most important predictors of self-control, adaptation and problem behaviors of individuals in later ages (Scaramella and Leve, 2004; Tahirović and Jusić, 2016). Many researches emphasize that memories of early ages have a data bank feature for the psychological problems observed in adult life (Brewin, Verews ve Gotlib, 1993; Canavarro ve Pereira, 2007; Matos, Pinto-Gouveia ve Duarte, 2013; Quirk, Wier, Martin, ve Christian, 2015). This shows that remembering positive and negative emotional memories of childhood is a good predictor of psychopathology (Richter and McEwan, 2010; Widom, Csaba, Nowakowski and Chauhan, 2018).

The schema is defined as a common theme or pattern that was developed in childhood and continued throughout the individual's life and related to his relationship with himself and with others (Richter, Gilbert, and McEwan, 2009). Schemas are extremely stable and permanent patterns of memories, somatic sensations, emotions, cognitions, and play a decisive role in understanding and making sense of life, events, people and relationships (Pelerine, Caparo and Trombone, 2016).

The symptoms that affect mental health negatively and are used to diagnose these are called psychological symptoms. Although there are many different classifications in the literature, the classification of SCL-90 which was accepted as the short form of this research and accepted by Derogates (1992) was adopted.

The aim of this research is to reveal relationship between incompatible cognitive schemes with happiness and peace memories in childhood and psychological symptoms, and also it is aimed to present findings to related persons on the predictive power along with determining which scheme field-aspect and which psychological symptom has higher relation with the happy and peace memories of the childhood period. In this general purpose framework, the answers of following questions were sought:

i. Which of the disconnection-rejection, impaired autonomy, impaired boundaries, alternativeoriented and hypovigilance-inhibition scheme fields are related with CHPM and on which rate?

ii. Which of abandonment, social isolation- insecurity, emotional deprivation, imperfection, nestedaddiction, weakness, failure, insufficient self-control- self-discipline, looking for confirmation, self sacrifice, negativity- pessimism, suppression of emotion, punisher and high standarts scheme dimensions are related with CHPM and on which rate?

iii. What is the predicting rate of anxiety, depression, negative self, somatization, and hostility symptoms to CHPM?

iv.What is the predicting rate of discomfort severity, symptom total and symptom discomfort indices to CHPM? 


\section{Method}

Relational screening model was used in the research. For this purpose, childhood happiness and peace memories scale developed by McEwan (2009), scheme scale developed by Young (1990) and short symptom screening inventroy developed by Derogatis (1992) were applied to 468 university students group from 5 different faculties of $40 \%$ of them female and $60 \%$ of them male. In the analysis of the data, correlation and regression techniques were used besides descriptive statistical values.

\section{Findings}

The highest correlation between the CHPM scores and the schema fields were determined between "hypovigilance- inhibition" "impaired boundaries" and "impaired autonomy" and this is consistent with the explanations of the schema and attachment theory. It is also important to determine that the five schema explain together account for about half of the total variance of the CHPM scores. In the research; also, detection of hypovigilance- inhibition, impaired autonomy, disconnection-rejection schema fields as the most powerful and significant predictors of CHPM is a proof of the effect of childhood experiences in determining schemas in later ages.

In the research, more detailed results were obtained from examining the relation between 14 schema dimensions and CHPM beside 5 schema fields. As a result of this detailed analysis, the highest correlation between the CHPM scores and schema dimensions were observed in punisher, negativity- pessimism and insufficient self-control and self-discipline-dimensions.

However, in the analysis; it was found that the dimensions of nested addiction, negativity pessimism, high standards, punisher, insufficient self-control-self-discipline, looking for confirmation scheme dimensions were found to be a significant predictor of CHPM scores.

The highest correlation between CHPM scores and psychological symptoms were found in "negative self and depression" dimensions. This may be interpreted as the findings of schemas are consistent with findings related to psychological symptoms. When the findings related to psychological symptoms are evaluated, it is seen that the frequency of symptoms decreases as the CHPM scores increase; and participants who declared less happiness and peace memories, the symptoms decrease. Determination of a significant, negative and high correlation between the Global Disability Severity Index and the CHPM is also an important finding which supports this situation. Similarly, the fact that the five symptoms together explain for 46 percent of the total variance on CHPM scores was another important evidence of the relationship between CHPM and psychological symptoms. Another important finding in the study is that the negative self is the strongest predictor of CHPM scores among the five psychological symptoms. The standardized regression coefficient calculated from the negative self-score is significantly higher than the coefficient of the other symptoms. 


\section{Discussion}

Findings; with "nested-addiction" which is defined as individual's belief on he cannot survive without support of others and cannot develop an individual personality and "negativity- pessimism" which is characterized with belittling positive aspects of life and focusing negative aspects schemes ranked among the top two in terms of relation with CHPM, is completely consistent with the findings obtained related to psychological symptoms. In the prioritizing of psychological symptoms on CHPM scores; "negative self, somatization and depression" ranked among the top three and this situation can be shown as another proof to consistency of the research results.

\section{Suggestions}

It has been suggested that research findings could be used to prepare and develop parenting education programs and to increase the effectiveness of preventive and developer guidance services in schools. 


\section{GİRİŞ}

Diğer türlerin çoğunun aksine, insan yavrusu zayıf ve savunmasız olarak doğar ve olgunlaşmak için çok zamana ihtiyaç duyar (Preston, 2013). Olgunlaşma sürecinde erken çocukluk dönemine ait yaşantıların kalitesi ve içeriği, ileriki yaşlarda psikolojik sağlığın, sağlıklı insan ilişkilerinin, akademik başarının, sosyal uyumun en önemli belirleyicisi olma özelliğini taşımaktadır (Nia, Sovani ve Forooshani, 2014). Başka bir ifadeyle, çocukluk çağı yaşantıları ileriki yaşlarda bireylerin kendi kendine kontrol, uyum ve problem davranışlarının en önemli yordayacılardır (Scaramella ve Leve, 2004; Tahirović ve Jusić, 2016). Yapılan pek çok araştırma erken yaşlara ilişkin anıların, yetişkin yaşamında gözlenen psikolojik sorunlar için bir veri bankası niteliği taşıdığını vurgulamaktadır (Brewin, Verews ve Gotlib, 1993; Canavarro ve Pereira, 2007; Matos, Pinto-Gouveia ve Duarte, 2013; Quirk, Wier, Martin ve Christian, 2015). Bu durum çocukluk dönemine ait olumlu ve olumsuz duygusal anıların hatırlanmasının psikopatolojinin iyi bir öngörücüsü olduğunu göstermektedir (Richter ve McEwan, 2010; Widom, Czaja, Kozakowski ve Chauhan, 2018). Yaşamın ilk on y1l için otobiyografik anıların niceliksel dağılımının incelendiği bir araştırmada, çocukluk dönemine ilişkin anıların yetişkin yaşamının psikolojik sağlığına ilişkin pek çok ip ucunu barındırdığı saptanmıştır (Rubin, 2000).

Erken çocukluk yılları ile psikopatoloji arasında ilişki arayan çalışmaların yanında, bu yıllarında yaşanan sıcaklık, güvenlilik ve olumlu duyguların, yetişkinlik yıllarına ait olumlu sonuçlarının olduğu gösteren araştırmalar da mevcuttur (Ferreira, Cunha, Marta- Simões, Duarte, Matos ve PintoGouveia, 2018; Schmoeger vd. 2018). Yapılan benzer çalışmada da erken pozitif ilişki deneyimleri ile yetişkin yaşamdaki psikososyal uyum arasındaki anlamlı ilişki bulunmuş; çocukluk ve ergenlik dönemine ait sıcaklık, güven ve sevgi ile karakterize yaşantıların, yetişkinlikteki iyi oluş ve akıl sağlığını yordayabildiği vurgulanmıştır (Cunha, Ferreira, Duarte, Andrade, Marta-Simões ve PintoGouveia, 2017).

Bununla birlikte, çocukluk dönemine ait sarsıcı yaşantıların yetişkinlik yaşamına etkisini konu alan araştırmaların sayısı daha fazladır. Bu çalışmaların tamamında, erken çocukluk deneyimlerinin ve bunlar arasında özellikle de tehdit veya güven duygusuyla ilişkili olanların sonraki gelişim dönemleri üzerinde olumsuz rol oynadığ1 vurgulanmıştır (Alto, Hveley, Rogosch, Cicchetti ve Toth, 2018). Özetlenen araştırmaların ortak vurgusu, yetişkinlik yaşamında gözlenen depresyon ve anksiyetenin çocukluk dönemine uzanan izlerinin bulunduğudur. Çocukluk dönemine ait olumsuz yaşantılar ile, olumsuz kimlik geliştirme, uyumsuz şemalar ve duygu düzenleme sorunları arasında ilişki arayan araştırmalar da mevcuttur (Schore, 2001; Mikulincer ve Shaver 2008; Gilbert ve Irons, 2009; Vveell Vd., 2010; Galhardo vd., 2011). Tüm bu araştırmalarda, yetişkin yaşamındaki psikolojik sorunlar ve 
uyumsuz şemaların, çocukluk dönemine ait anılar kullanılarak açıklanmasına hizmet ettiğini vurgulamaktadır (Vagos, Ribeiro da Silva, Brazão, Rijo ve Gilbert, 2017).

Şema, çocukluk döneminde geliştirilen ve kişinin yaşamı boyunca devam eden, kendisi ve başkalarıyla olan ilişkisine dair yerleşik, yaygın bir tema veya örüntü olarak tanımlanmıştır (Richter, Gilbert ve McEwan, 2009). Şemalar; anıların, bedensel duyumların, duyguların, bilişlerin oluşturduğu son derece kararlı ve kalıcı kalıplardır ve yaşamı, olayları, insanları ve ilişkileri anlama ve anlamlandirmada belirleyici bir role sahiptir (Pellerone, Craparo ve Tornabuoni, 2016). Bununla birlikte bireyin, kendisi ve yaşadığı dünya ile ilgili sabit ve tutarlı izlenim sürdürme çabası olarak da bilinen "bilişsel tutarlılık" ihtiyacını karşılar. Young, Klosko ve Weishaar, (2003) şemaların beş önemli özelliği bulunduğunu belirtmiştir: Şemalar, geniş, yaygın temalar ya da örüntülerdir. Anılardan, duygulardan, algılardan ve bedensel duyumlardan oluşur. Çocuklukta ya da ergenlik döneminde gelişirler, kişinin hayatı boyunca işlenmeye devam ederler ve önemli ölçüde işlevsizdirler.

Şemaların kaynağı genellikle travmatik, ya da en azından yıkıcıdır ve birçoğu çocukluk ve ergenlik dönemi boyunca tekrarlanan zarar verici deneyimler sonucu ortaya çıkar. Bu zararlı tekrarlayan deneyimler birikerek şemaları oluşturur. En zarar verici şemalar, çocukluk dönemindeki terk edilme, istismar, ihmal ya da reddedilmenin etkilerinden oluşur (Young, Klosko ve Weishaar, 2003; Martin ve Young, 2010).

Şemaların gelişiminde en önemli kaynağın, çocukluk çağındaki temel duygusal ihtiyaçların karşılanmaması olduğunu ileri süren Young, evrensel olduğuna inandığı 5 temel ihtiyaçtan bahseder (Young, Klosko ve Weishaar, 2003). Bunlar; başkalarına güvenli bağlanma (Secure attachment to others/ includes safety, stability, nurturance ve acceptance), Özerklik, yeterlilik ve kişilik alg1s1 (Autonomy, competence ve sense of identity), ihtiyaçların ve duyguların ifade edilme özgürlüğü (Freedom to express valid needs ve emotions), kendiliğindenlik ve oyun (Spontaneity ve play) ve gerçekçi sınırlar ve özdenetimdir (Realistic limits ve self-control). Küçük yaşlarda gelişen erken dönem uyumsuz şemaların temelinde de bu temel duygusal ihtiyaçların karşılanmaması yatar. Bununla birlikte travmatize edilme, aşırı korunma, önemli diğer kişilerin seçici içselleştirilmesi veya seçici özdeşim kurma şemaların gelişmesinde rol oynayan önemli faktörlerdir (Young vd., 2003).

Young ve Brown (1994), 5 şema alanı altında sınıflandırdığı şema boyutlarına ilişkin özet bilgi Tablo 1'de gösterilmiştir. 
Tablo 1. Şema Alanları, Şema Boyutları ve İçeriği

\begin{tabular}{|c|c|c|}
\hline $\begin{array}{l}\text { Şema } \\
\text { Alanı }\end{array}$ & Şema Boyutları & Özet Bilgi \\
\hline 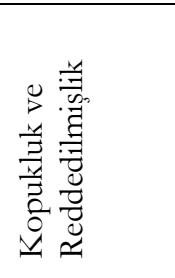 & $\begin{array}{l}\text { Terk Edilme ya da İstikrarsıllık } \\
\text { Güvensizlik ya da Suiistimal Edilme } \\
\text { Duygusal Yoksunluk } \\
\text { Kusurluluk ya da Utanç } \\
\text { Sosyal İzolasyon, Yabancılaşma }\end{array}$ & $\begin{array}{l}\text { Bu alanda şemalara sahip olan bireyler başka insanlarla ile güven } \\
\text { verici ve tatmin edici bir ilişki kurmada sorun yaşamaktadırlar. Bu } \\
\text { bireyler istikrarlı olma, güvenli bir ortam oluşturma, bakım, } \\
\text { sevgiye sahip olma, mensubiyet, empati kurma, kabul edilme, } \\
\text { duyguların tam ve doğru bir şekilde aktarılması gibi ihtiyaçların } \\
\text { karşı taraftaki bireylerce karşılanamayacağına dair inanç } \\
\text { sergilemektedir. }\end{array}$ \\
\hline 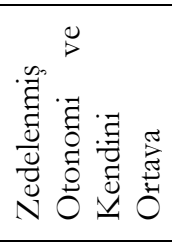 & $\begin{array}{l}\text { Bağımlılık ya da Yetersizlik } \\
\text { Hastalıklar ve Tehditler } \\
\text { Karşısında Dayanıksızlık } \\
\text { İç İçelik ya da Gelişmemiş Benlik } \\
\text { Başarısızlık ya da Yetersizlik }\end{array}$ & $\begin{array}{l}\text { Bu şemaya sahip bireyler ebeveynlerinden farklılaşamamıs ve } \\
\text { dolayısıyla birey olamamışlardır. Bu bireyler, aşırı korumacı } \\
\text { ailelere sahip olabildikleri gibi tam tersi özelliğe sahip ailelerde } \\
\text { olabilmektedir. Ailelerin ebeveynlik tutumları çocukların kendine } \\
\text { olan güvenlerinin gelişmesini engelleyerek, yetişkinlik döneminde } \\
\text { kendi yaşamlarını kurmalarını engellemektedir. }\end{array}$ \\
\hline 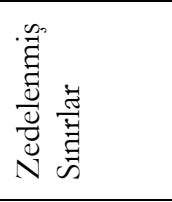 & $\begin{array}{l}\text { Hak Görme ya da Büyüklük } \\
\text { Yetersiz Özdenetim }\end{array}$ & $\begin{array}{l}\text { Bu şema alanı bireyin kendisine disiplin uygulamasında zorluk } \\
\text { çekmeye yönelik şemaları içermektedir. Bu bireyler, haklara sayg1 } \\
\text { göstermede, uyum sağlamada, sözlerini tutmada zorluk } \\
\text { yaşamaktadır. Çoğunlukla bu bireyler sorumluluk duygusu } \\
\text { olmayan bencil ve narsistik bir yapıdadır. }\end{array}$ \\
\hline 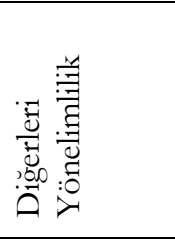 & $\begin{array}{l}\text { Boyun Eğicilik } \\
\text { Onay Arayıcılık } \\
\text { Kendini Feda }\end{array}$ & $\begin{array}{l}\text { Bu şemaya sahip bireyler onaylanmak, ilişkiyi duygusal yönde } \\
\text { devam ettirmek ya da oluşabilecek olumsuzluklardan kaçmak için } \\
\text { başkalarının varlığını olması gerektiğine inanmaktadır. } \\
\text { Başkalarıyla ilişkilerinde kendi gereksinimlerinden fazla } \\
\text { başkalarının tepkilerinin ne olacağını düşündüğünden kendi } \\
\text { tercihlerine veya öfkelerine yönelik farkındalıkları azdır. }\end{array}$ \\
\hline 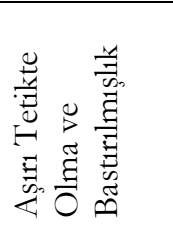 & $\begin{array}{l}\text { Karamsarlık } \\
\text { Duyguları Bastırma, } \\
\text { Yüksek Standartlar ya da Aşırı } \\
\text { Eleştiricilik Cezalandırıcılık }\end{array}$ & $\begin{array}{l}\text { Batırılmış şemaya sahip bireyler içselleştirilmiş standartlara } \\
\text { ulaşmak için, kendi mutluluklarından, kendini anlatmaktan } \\
\text { çekinirler. Endişe duygusu yüksek, korku dolu ve tetikte } \\
\text { olmadıkları takdirde yaşamlarının yok olacağı beklentisi içinde } \\
\text { olan bireylerin kökeninde genellikle bastırılan, kendi isteklerinden } \\
\text { bastırlmış bir çocukluk geçmişleri mevcuttur }\end{array}$ \\
\hline
\end{tabular}

Literatürde, yetişkin bireylerde gözlenen şema alanları ve şema boyutları ile çocukluk ve ergenlik yaşantılanı arasında ilişki arayan çok sayıda araştırma mevcuttur. Erken çocukluk yaşantıları ve uyumsuz kişilerarası şemalar arasındaki ilişkiler (Kaya, Tutarel ve Boysan (2015), erken ebeveyn etkileşimi ve bilişsel şemalar (O’Dougherty, Crawford ve Del Castillo, 2009), çocukluk dönemi duygusal istismar yaşantıları, bağlanma stilleri ve erken uyumsuz şemalar (Gay, Harding, Jackson, Burns ve Baker, 2013), bilișsel șemaların olușmasında anne bakımının etkisi ve baba kontrolünün rolü (Pellerone, Craparo ve Tornabuoni, 2016), şema alanları ile çocuklukta hatırlanan ebeveyn deneyimleri (Bach, Lockwood ve Young, 2018), güven-güvensizlik ve şemalar (Baldwin ve Dveeneau, 2005) bunlardan bazılarıdır.

Yapılan araştırmanın bir diğer değişkeni psikolojik semptomlardır. Dünya Sağlık Örgütünün tanımına göre akıl ve ruh sağlığg: "bireyin yeteneklerinin farkında olması, yaşamın normal stresleriyle baş edebilmesi, üretken olması ve içinde bulunduğu topluma katkıda bulunması" olarak tanımlanmıştır. (WHO, 2011). Freud, haz ilkesi ve gerçeklik ilkesi arasında denge kurmayı (BorchJacobsen ve Shamdasani, 2012); Erikson, gelişim aşamalardaki unsurlardan sağlıklı olanların sağlıksız olanlardan fazla olmasını (Schachter, 2018); Maslow, Kendini gerçekleştirmekte olan 
kişinin kendiyle ilgili objektif ve tutarlı bir görüşe sahip olmayı, doğanın ve başka insanların değerini bilmeyi, evrensel insan değerlerini benimsemeyi, zamanını faydalı kullanmayı, üretici, açık fikirli olmayı (Acevedo, 2018); Rogers, yaşantılara açık, her anı dolu yaşama eğilimli, düşünce ve davranışlarda özgür ve yaratıcı olmayı (Shefer, Carmeli ve Cohen- Meitar, 2018) ruh sağlığının ölçütleri olarak öngörmüştür.

Ruhsal sağlığ1 olumsuz olarak etkileyen ve bunların teşhisine yarayan belirtilere ise psikolojik semptomlar ismi verilir. Literatürde çok farklı sınıflamalar bulunmasına karşıllı, bu araştırmada SCL-90-R'nin kısa formu olarak kabul edilen ve Derogatis (1992) tarafindan öne sürülen sinıflama benimsenmiştir. Bu sınıflamaya göre, anksiyete, depresyon, olumsuz benlik, somatizasyon ve hostilite, bireylerde en sık gözlenen beş psikolojik semptom grubudur.

Somatizasyon, fiziksel bulgularla açıklanamayan bedensel şikâyet ve belirtilerdir (Fishbain, Lewis, Gao, Cole ve Steele Rosomoff, 2009). Somatizasyona yatkın olan bireylerin ortak özelliği; duygusal uyaranlara karşı tepkilerinin duygusal ya da bilişsel olmaktan öte bedensel olmasıdır (Shettar, Kakunje, Karkal, Mendonsa, Kini ve Mohan Chveran, 2018). Somatizasyona genellikle depresyon ya da anksiyete gibi bir psikolojik rahatsızlık da eşlik eder (Burton, Farley ve Rhea, 2009).

Depresyon genel anlamıyla bir ruhsal çökkünlük durumudur. Depresyonda üzüntülü, bunaltılı bir duygu durumun beraberinde düşüncede, konuşmada, hareketlerde yavaşlamalar görülür. Bunların yanında kişide değersizlik, güçsüzlük, isteksizlik, karamsarlık, pişmanlık duyguları baskın hale gelir (Klemanski, Curtiss, McLaughlin ve Nolen-Hoeksema, 2017). Aynı zamanda iştahta, cinsel istekte, uyku düzeninde bozukluklar gözlemlenir (Karen, 2018). Anksiyete, fiziksel duyumların da ortaya çıkabildiği, bir tür korku ve endişe duygusudur. Göğüste sıkışma, kalp çarpıntısı, terleme, baş ağrısı, midede boşluk duygusu ve hemen tuvalete gitme isteği gibi duyumlar gözlemlenebilir (Vallance ve Garralda, 2011; Jones - Rincon ve Howard, 2018). Olumsuz benlik; bireyin kendini başkalarıyla kıyaslaması, kendini değersiz olarak nitelendirip aşağılaması, özünü reddetmesi, rahat ve doğal olamaması, aşı1 derecede öz farkındalığı olması ve bunlara bağlı olarak olumsuz beklentileri olmasıdır (Ghorbani, Pourhosein ve Ghobadi, 2018). Hostilite, husumet, iftira, kötülük içeren ve öfke duygusunun etkileri ile ortaya çıkan olumsuz bir tutumdur. Başkalarına zarar verme, intikam alma, acı çektirme isteklerini içerir (Hollve, Mitchell, Steele, Bunting ve Harrison, 2018).

Psikolojik semptomların çocukluk ve ergenlik dönemi yaşantıları ile ilişkisi pek çok araştırmanın konusu olmuştur. Somatizasyon ile çocukluk dönemi yaşantıları (Bursch, 2010; Garralda, 2011), depresyon ve anksiyete ile erken çocukluk çağı ebeveyn çocuk ilişkisi (Long, Young ve Hankin, 2018; Gledhill ve Hodes, 2011), çocuklarda ve ergenlerde hostilitenin kaynakları (Caprara, Paciello, Gerbino ve Cugini, 2007; Dijk, Poorthuis, Thomaes ve Castro, 2018; Allan, Kashani ve Reid, 1998), olumsuz benlik gelişiminde ebeveyn rolleri (Karen, 2018) bunlardan bazılarıdır. 
$\mathrm{Bu}$ araştırmanın amacı, çocukluk dönemi mutluluk ve huzur anıları ile uyumsuz bilişsel şemalar ve psikolojik semptomlar arasındaki ilişkiyi ortaya koymaktır, Hangi şema alanının-boyutunun ve hangi psikolojik semptomun, çocukluk dönemi mutluluk ve huzur anıları ile daha yüksek bir ilişki içerdiği belirlenerek önleyici ve geliştirici rehberlik ve psikolojik yardım konularında ilgili kişilere bulgular sunmak hedeflenmiştir. Bu genel amaç çerçevesinde aşağıdaki sorulara cevap aranmıştır:

i. Kopukluk-reddedilme, zedelenmiş otonomi, zedelenmiş sınırlar, diğerlerine yönelimlilik ve aşırı tetikte olma-ketlenme şema alanlarından hangileri ne orvea ÇDMHA ile ilişkilidir?

ii. Terk edilme, sosyal izalasyon-güvensizlik, duygusal yoksunluk, kusurluluk, iç içe geçmebağımlılık, dayanıksızlık, başarısızlık, yetersiz özdenetim-öz disiplin, onay arayıcılık, kendini feda, olumsuzluk-karamsarlık, duyguları bastırma, cezalandırıcılık ve yüksek standartlar? şema boyutlarından hangileri ne orvea ÇDMHA ile ilişkilidir?

iii. Anksiyete, depresyon, olumsuz benlik, somatizasyon ve hostilite semptomlarının ÇDMHA'nı öngörme oranı nedir?

iv. Rahatsızlık ciddiyeti, belirti toplam ve semptom rahatsılılk endekslerinin ÇDMHA'nı öngörme oranı nedir?

\section{YÖNTEM}

Araştırmada ilişkisel tarama yöntemi kullanılmıştır. Bu amaçla aşağıda ayrıntıları açıklanan, çocukluk dönemi mutluluk ve huzur anıları ölçeği, şema ölçeği ve kısa semptom tarama envanteri 468 kişilik öğrenci grubuna uygulanmıştır. Araştırma grubuna, veri toplama araçlarına ve analiz yöntemlerine ilişkin bilgiler aşağıda verilmiştir.

\section{Evren, Çalışma Evreni ve Örneklem}

Araştırmanın evrenini üniversite öğrencileri oluşturmaktadır. Çalışma evreni olarak Necmettin Erbakan Üniversitesinin öğrencileri belirlenmiştir. Çalışma grubunun oluşturulmasında küme örnekleme yöntemi kullanılmıştır. Mühendislik, Tıp, İktisat-işletme, eğitim ve ilahiyat fakültelerden 100’er öğrenci, her sınıf düzeyine eşit miktarda dağılacak şekilde ve gönüllülük ilkesine bağlı olarak seçilmiştir. Böylece 500 kişilik bir örneklem büyüklüğü hedeflenmiştir. Bilgi toplama araçlarından eksik ve yanlış doldurulanlar ayıklandıktan sonra 462 öğrenciye ait veriler değerlendirmeye alınmıştır. Örnekleme ilişkin bilgiler Tablo 2'de gösterilmiştir.

Tablo 2. Çalısma grubunun özellikleri

\begin{tabular}{|c|c|c|c|c|c|}
\hline Cinsiyet & $\mathrm{f}$ & $\%$ & Fakülteler & $\mathrm{f}$ & $\%$ \\
\hline Kadın & 277 & 60 & Mühendislik & 91 & 19.7 \\
\hline Erkek & 185 & 40 & Tip & 88 & 19.1 \\
\hline Yas & 462 & 100.0 & İktisat-İşletme & 93 & 20.1 \\
\hline
\end{tabular}




\begin{tabular}{llllll}
\hline 18 ve az & 118 & 25.5 & Ĕgitim & 96 & 20.8 \\
$19-21$ & 182 & 39.4 & Illahiyat & 94 & 20.3 \\
$22-24$ yaş & 162 & 35.1 & Toplam & 462 & 100.0 \\
Toplam & 462 & 100.0 & & & \\
\hline
\end{tabular}

Tablo 2'de görüldüğü gibi çalışma grubunun \%60 kadın, \%40’1 erkeklerden oluşmaktadır. 18 ve daha küçük yaştaki katılımcıların oranı 25.5, 19-21 yaş grubunun 39.4 ve 22-24 yaş grubunun ise 35.1'dir. Öğrencilerin altı fakülteye dağılımları ise yaklaşık olarak birbirine yakındır.

\section{Veri Toplama Araçları}

Çocukluk dönemi mutluluk ve huzur anıları ölçeği, Richter, Gilbert, McEwan (2009) tarafindan bireylerin çocukluk döneminde iken yaşadıkları anıları değerlendirmek amacıyla geliştirilmiştir. 20 maddeden oluşan ölçekte puanlardaki artış, bireyin çocukluğuna yönelik yüksek seviyede mutluluk ve huzur anılarına sahip olduğunu işaret etmektedir. Ölçeğin geçerlik güvenirlik çalışması ve Türkçe uyarlaması, Akın, Uysal, Çitemel, (2013) tarafindan yapılmıştır. Ölçeğin yapı geçerliğine ilişkin uygulanan açımlayıcı faktör analizinde 20 maddeden tek boyuta yönelik yapı elde edilmiştir. Ölçeğin tek boyutlu yapısı ise toplam varyansın \%64'ünü açıklamakta ve maddelerin faktör yükleri 0,64-0,85 aralığında değişmektedir. Ölçeğin iç tutarlılık güvenirlik katsayısı 0,97 iki hafta ara ile uygulanan test tekrar test korelasyonu katsayısı ise 0,91 olarak elde edilmiştir. (Akın, Uysal, Çitemel, 2013).

Young (1990) tarafından geliştirilen ve bir yıl sonra yılında revizyonu yapılan Şema Ölçeği, 16 erken dönem uyumsuz şemayı ölçmeyi amaçlayan bir öz bildirim ölçeğidir. Young Şema Ölçeği’nin hem uzun hem de kısa formu bulunmaktadır. Young ve Brown tarafindan (1994), uzun formda yer alan her şemanın en yüksek faktör yüküne sahip 5'er maddenin seçilmesi ile 75 maddelik bir kısa form geliştirmiştir. Ölçeğin içsel tutarlılık katsayıları $\alpha=.83$ ile $\alpha=.96$ arasında yer almış, daha sonra yapılan bir çalışmada da Burton vd. (2009) ölçeğin test-tekrar test güvenirliğinin .50 ile .82 arasında olduğunu rapor etmiştir.

Young Şema Ölçeği Kısa Form-3’ün Türkçe Formunun Faktör Yapısı Ölçeğin psikometrik Özelliklerine yönelik çalışma Soygüt, Karaosmanoğlu ve Çakır (2009) tarafindan, yapılmıştır. Bu çalışmada ilk olarak 15 faktör ortaya çıkmış ancak son faktörü oluşturan 27. ve 45. maddeler bu faktörün İç İçe Geçme/Gelişmemiş Benlik faktörünün tekrarı olduğu düşünülerek ölçek dış1 bırakılmıştır. Bu faktörlerin toplam varyansın \%49.11'ini açıklama gücüne sahip olduğunu göstermiştir. 14 faktörün belirlenmesinden sonra üst-sıra (higher order) faktör analizi yürütülmüş ve beş faktörlü yapının uygun olduğuna karar verilmiştir. Uyarlama çalışmasında ölçeğin iç tutarlık katsayılarının .66 ile.82 aralığında değiştiği saptanmıştır. 
Kisa Semptom Envanteri (Brief Symptom Inventory) genel bir psikopatoloji değerlendirmesi yapacak kısa ancak geçerli ve güvenilir olan ölçeklere duyulan ihtiyaç üzerine Derogatis (1992) tarafından geliştirilmiş Likert tipi kendini değerlendirme türü bir envanterdir. Kısa Semptom Envanteri, SCL-90-R ile yapılan çalışmalar sonucunda ortaya çıkan SCL-90-R'nin kısa formudur. SCL-90-R' nin dokuz faktörüne dağılmış olan 90 madde arasından, her faktörde en yüksek yükü almış toplam 53 madde seçilmiştir. Şahin ve Durak (2002) tarafından yapılan Türkiye uyarlamasında KSE'nin “Anksiyete”, "Depresyon”, “Olumsuz Benlik", "Somatizasyon” ve "Hostilite" olmak üzere beş faktörden oluştuğu bulunmuştur. Şahin ve Durak (2002) yapılan çalışmalarda KSE'nin güvenirliği kontrol edilmiştir. Ölçeğin üç ayrı çalışmada iç tutarlığı toplam puanından elde edilen Cronbach Alpha iç tutarlılık katsayıları .96 ve .95; alt ölçekler için elde edilen katsayılar ise .55 ile .86 arasında değişmektedir. Yurtdışında yapılan araştırmalarda bu değerin .71 ve .85 arasında olduğu belirtmiştir (Savaşır ve Şahin, 1997).

Araştırmada toplanan verilerin güvenirliğini sağlamak için bulgulann değerlendirilmesinden önce üç ölçeğin iç tutarlık ve uyum endeksleri hesaplanmıştır. Bu analizler sonunda araştırmada kullanılan ölçeklerin yeterli iç tutarlık katsayısına sahip oldukları ve uyum endekslerinin veriye iyi uyum sağladığ1 görülmüştür.

Bu araştırma için hesaplanan üç ölçeğe ait iç tutarlık katsayıları Tablo 3'de gösterilmiştir.

Tablo 3: Araştırmada kullanılan üç ölçeğin iç tutarlık katsayıları

\begin{tabular}{lcc}
\hline Ölçekler & İfade Sayısı & Cronbach's Alpha $(\alpha)$ \\
\hline ÇDMHA & 20 & 0.893 \\
Şema & 90 & 0.805 \\
Psikolojik Semptomlar & 53 & 0.838 \\
\hline
\end{tabular}

Tablo 3'de görüldüğü üzere üç ölçeğin iç tutarlık katsayıları .805 ile .893 arasındadır. Bu değerleri ölçeklerin yeterli güven düzeyine sahip olduğunu göstermektedir.

Araştırmada kullanılan üç ölçeğe ait uyum endekslerine ilişkin sonuçlar Tablo 4'de gösterilmiştir.

Tablo 4. Araştırmada kullanılan üç ölçeğin uyum endekslerine ilişkin sonuçlar

\begin{tabular}{lcccccccc}
\hline & RMSEA & NFI & CFI & IFI & GFI & TLI & AGFI & CMIN/DF \\
\hline ÇDMHA & 0.080 & 0.957 & 0.954 & 0.953 & 0.894 & 0.934 & 0.828 & 1.895 \\
Şema & 0.081 & 0.952 & 0.907 & 0.909 & 0.873 & 0.891 & 0.829 & 1.893 \\
Psikolojik Semp. & 0.000 & 0.991 & 1.000 & 1.009 & 0.994 & 1.017 & 0.985 & 0.407 \\
Model Uyum & RMSEA & ,95 $\leq$ & $0,90 \leq$ &, $95 \leq$ & $0,90 \leq$ &, $95 \leq$ & $0,90 \leq$ & $X^{2} /$ sd $\leq 3$ \\
Kriterleri & $\leq 0,05$ & NFI & GFI & IFI & GFI & TLI & AGFI & \\
\hline
\end{tabular}


Araştırmada kullanılan üç ölçeğin de uyum değerlerinin iyi ve kabul edilebilir düzeyde olduğu saptanmıştır.

\section{BULGULAR}

\section{Şema Alanları ile Çocukluk Dönemi Mutluluk ve Huzur Anıları (ÇDMHA) Arasındaki İlişkiye Ait Bulgular}

On dört şema boyutunun gruplandırılmasından oluşan beş şema alanının ÇDMHA ile ilişkisine ait bulgular Tablo 5’te gösterilmiştir.

Tablo 5. Çocukluk dönemi mutluluk ve huzur anıları ile bilişsel şema alanları arasındaki ilişkiye ait bulgular

\begin{tabular}{|c|c|c|c|c|c|c|c|c|c|}
\hline & Art.Ort. & Medyan & ss & $\mathrm{r}$ & $\mathrm{B}$ & $\mathrm{SH}$ & $\beta$ & $\mathrm{t}$ & Sig \\
\hline (sabit) & & & & & 137.166 & 5.93 & & 23.117 & .000 \\
\hline Kopukluk- Reddedilme & 2.93 & 2.91 & .54 & $-.515^{* *}$ & -5.905 & 3.16 & -.242 & -2.137 & $.035^{*}$ \\
\hline Zedelenmiş Otonomi & 3.13 & 3.15 & .57 & $-.456^{* *}$ & -6.080 & 3.33 & -.265 & -2.021 & $.040^{*}$ \\
\hline Zedelenmiş Sınırlar & 3.00 & 3.04 & .67 & $-.541^{* *}$ & -3.569 & 2.35 & -.181 & $-1,989$ & $.046^{*}$ \\
\hline Diğerlerine Yönelimlilik & 3.01 & 3.07 & .61 & $-.500^{* *}$ & -1.336 & 2.56 & -.061 & -.522 & .603 \\
\hline Aşır1 Tetikte Olma Ketlenme & 2.98 & 3.00 & .54 & $-.642^{* *}$ & -11.725 & 3.69 & -.484 & -3.173 & $.002^{* *}$ \\
\hline $\begin{array}{lll}\mathrm{R}=.666 & \mathrm{R}^{2}=.443 & \text { Düze } \\
\mathrm{F}=16.229 & p<.000 & \\
\end{array}$ & mic $\mathrm{R}^{2}=$ & & & & & & & & \\
\hline
\end{tabular}

Araştırma örneklemini oluşturan bireylerin, beş şema alanına ait tanımlayıcı istatistik değerlerinin (zedelenmiş otonomi Ort= 3.13, Ortanca $=3.15, \mathrm{ss}=0.57$; zedelenmiş sinırlar; Ort $=3.01$, Medyan $=$ 3.07, ss. $=0.61$; diğerlerine yönelimlilik Ort. $=3.00$, Medyan $=3.04, s s=0.67$; aşır1 tetikte olmaketlenme Ort. $=2.98$, Medyan $=3.00$, ss. $=0.54$ ve "kopukluk-reddedilme" $($ Ort. $=2.93$, Medyan $=2.91$, $s s .=0.54)$ birbirine yakın bulunması, bilişsel şema alanları puanlarının normal dağılım gösterdiğine işaret etmektedir. Bu durumun daha ileri analiz sonuçlarının güvenirliğini artırması beklenmektedir.

ÇDMHA puanları ile şema alanları arasında en yüksek korelasyon, "aşırı tetikte olma - ketlenme" $(\mathrm{r}=.642, \mathrm{p}<.000)$ 'de gözlenmiştir. İkinci sırada yüksek korelasyon ise "zedeleniş sınırlar" ( $\mathrm{r}=.541$, $\mathrm{p}<.000)$ alanında saptanmıştır. Göreceli olarak “zedelenmiş otonomi $(r=.456 \mathrm{p}<.002)$ diğer şema alanları arasında, göreceli olarak ÇDMHA ile en düşük korelasyona sahip alan olarak tespit edilmiştir. Bununla birlikte ÇDMHA ile beş şema alanı arasındaki korelasyonlar orta ve yüksek düzeyde ve istatistiksel bakımdan anlamlıdır. Bu durum ÇDMHA ile yetişkinlikte gözlenen bilişsel şemaların ilişkisini göstermesi bakımından önemli görülmüştür.

Yapılan regresyon analizinde de bilişsel şema alanları (kopukluk- reddedilme, zedelenmiş otonomi, zedelenmiş sınırlar, diğerlerine yönelimlilik ve aşırı tetikte olma-ketlenme) birlikte, ÇDMHA puanlarıyla aralarında yüksek düzeyde ve anlamlı bir ilişki saptanmıştır. $\left(R=.666, R^{2}=.443, p<0.00\right)$. Beş şema alanı birlikte, ÇDMHA puanlarına ilişkin toplam varyansın \%44.3'ünü açıklamaktadır. Bu 
durum, ÇDMHA ile bilişsel şemalar arasındaki ilişkiyi gösteren bir diğer önemli kanıt olarak değerlendirilmiştir.

Standartdize edilmiş regresyon katsayısına $(\beta)$ göre, yordayıcı değişkenlerin ÇDMHA puanları üzerindeki göreli önem sırası; aşırı tetikte olma - ketlenme $(\beta=-.484)$, zedelenmiş otonomi $(\beta=$ .265), kopukluk-reddedilme ( $\beta=-.242)$, zedelenmiş sınırlar $(\beta=-.181)$ ve diğerlerine yönelimlilik $(\beta=-.061)$ şeklindedir. Regresyon katsayılarının anlamlılı̆̆ına ilişkin t-testi sonuçları incelendiğinde ise, kopukluk- reddedilme $(\mathrm{t}=-2.137, \mathrm{p}<.035)$, zedelenmiş otonomi $(\mathrm{t}=-2.021, \mathrm{p}<.040)$, zedelenmiş sınırlar $(\mathrm{t}=-1.989, \mathrm{p}<.046)$ ve aşırı tetikte olma-ketlenme $(\mathrm{t}=-3.173, \mathrm{p}<.002)$ şema alanlarının ÇDMHA puanlarının anlamlı bir yordayıcısı olduğu söylenebilir. Regresyon analizi sonuçlarına göre, Şema alanlarının ÇDMHA'nı yordamasına ilişkin denklem şu şekilde oluşmuştur:

ÇDMHA $=137.166+($ kopukluk-reddedilme $\mathrm{x}-5.905)+($ zedelenmiş otonomi $\mathrm{x}-6.080)+$ (zedelenmiş sınırlar x -3.569) + (diğerlerine yönelimlilik x -1.336) + (aşı1ı tetikte olma ketlenme x $11.725)$

\section{Şema Boyutları ile Çocukluk Dönemi Mutluluk ve Huzur Anıları (ÇDMHA) Arasındaki İlişkiye Ait Bulgular}

On dört şema boyutunun ÇDMHA ile ilişkisine ait bulgular Tablo 6'da gösterilmiştir.

Tablo 6. Çocukluk dönemi mutluluk ve huzur anıları ile bilişsel şema boyutları arasındaki ilişkiye ait bulgular

\begin{tabular}{|c|c|c|c|c|c|c|c|c|}
\hline & Ort. & ss & $\mathrm{r}$ & $\mathrm{B}$ & $\mathrm{SH}$ & Beta & $\mathrm{t}$ & Sig. \\
\hline (Sabit) & & & & 135.61 & 6.36 & & 21.30 & .000 \\
\hline Terk Edilme & 2.77 & .60 & -.434 & -1.881 & 2.10 & -.086 & -.892 & .374 \\
\hline Sosyal İzalasyon Güvensizlik & 2.56 & .64 & -.471 & -3.017 & 2.55 & -.146 & -1.183 & .240 \\
\hline Duygusal Yoksunluk & 2.94 & .91 & -.322 & .491 & 1.43 & -.034 & .343 & .732 \\
\hline Kusurluluk & 2.63 & .55 & -.319 & .934 & 2.09 & -.039 & .445 & .657 \\
\hline İç içe Geçme Bağımlılık & 3.01 & .62 & -.271 & 6.060 & 2.33 & -.286 & 2.601 & .011 \\
\hline Dayanıksızlık & 2.61 & .75 & -.470 & -.297 & 1.89 & -.017 & -.157 & .876 \\
\hline Başarısızlık & 2.76 & .70 & -.389 & 1.196 & 1.86 & -.063 & .643 & .522 \\
\hline Yetersiz Özdenetim Öz disiplin & 3.00 & .67 & -.541 & -4.025 & 2.31 & -.204 & $-1,997$ & .045 \\
\hline Onay Arayıcılık & 2.98 & .66 & -.514 & -3.880 & 1.97 & -.193 & $-1,990$ & .047 \\
\hline Kendini Feda & 3.04 & .75 & -.359 & -.658 & 1.88 & -.037 & -.349 & .728 \\
\hline Olumsuzluk Karamsarlık & 2.54 & .79 & -.571 & -3.127 & 1.72 & -.187 & $-2,520$ & .012 \\
\hline Duygular1 Bastırma & 3.27 & .85 & -.241 & .915 & 1.60 & -.059 & .569 & .571 \\
\hline Cezalandırıcılık & 3.02 & .60 & -.587 & -5.126 & 2.32 & -.234 & -2.209 & .030 \\
\hline Yüksek Standartlar & 3.08 & .73 & -.533 & -3.917 & 1.68 & -.217 & -2.329 & .022 \\
\hline $\begin{array}{lll}\mathrm{R}=.746 & \mathrm{R}^{2}=.557 & \text { Düzeltiln } \\
\mathrm{F}=8.358 & \mathrm{p}<.000 & \end{array}$ & Ş $\mathrm{R}^{2}=$ & & & & & & & \\
\hline
\end{tabular}


Araştırma örneklemini oluşturan bireylerin, 14 şema boyutuna ait aritmetik ortalamalar incelendiğinde, duygular1 bastırma (Ort. $=3.27$, ss. $=0.85)$, yüksek standartlar $($ Ort. $=3.08$, ss. $=0.73)$ ve kendini feda $($ Ort. $=3.04$, ss. $=0.75)$ boyutlarının en yüksek ortalamaya sahip bilişsel şema boyutu olduğu görülmektedir. 14 şema boyutu arasında göreceli olarak en düşük ortalamaya sahip boyutlar ise, dayanıksızlık $($ Ort. $=2.61$, ss. $=0.75)$, sosyal izalasyon güvensizlik $($ Ort. $=2.56$, ss. $=0.64)$ ve olumsuzluk karamsarlık $($ Ort. $=2.54$, ss. $=0.79)$ boyutlarıdır.

ÇDMHA puanları ile şema boyutları arasında en yüksek korelasyon, cezalandırıcılık $(\mathrm{r}=-.587$, $\mathrm{p}<.000)$, olumsuzluk karamsarlık $(\mathrm{r}=-.571, \mathrm{p}<.000)$ ve yetersiz özdenetim öz disiplin $(\mathrm{r}=-.541$, $\mathrm{p}<.000$ ) boyutlarında gözlenmiştir. ÇDMHA ile 14 şema boyutu arasında göreceli olarak en düşük korelasyonlar ise, kusurluluk $(\mathrm{r}=-.319, \mathrm{p}<.000)$, iç içe geçme bağımlılık $(\mathrm{r}=-.271, \mathrm{p}<.002)$ ve duyguları bastırma $(\mathrm{r}=-.241, \mathrm{p}<.003)$ boyutlarında saptanmıştır. ÇDMHA ile 14 şema boyutunun tamamı arasındaki korelasyonların anlamlı olması, ÇDMHA ile bilişsel şemaların ilişkisini göstermesi bakımından önemli bulunmuştur.

Yapılan regresyon analizinde, 14 bilişsel şema boyutunun birlikte, ÇDMHA puanlarıyla aralarında yüksek düzeyde ve anlamlı bir ilişki saptanmıştır. $\left(\mathrm{R}=.746, \mathrm{R}^{2}=.557, \mathrm{p}<0.00\right)$. On dört şema boyutu birlikte, ÇDMHA puanlarına ilişkin toplam varyansın \% 55.7'sini açılamaktadır. Diğer bir ifade ile yetișkinlikteki uyumsuz bilișsel șemaların \%56'sı ÇDMHA ile ilișkilidir. Bu durum, çocukluk dönemi yaşantıları ile bilişsel şemalar arasındaki ilişkiyi gösteren bir diğer diğer önemli kanıt olarak görülmüştür.

Standartdize edilmiş regresyon katsayısına $(\beta)$ göre, yordayıcı değişkenlerin ÇDMHA puanları üzerindeki göreli önem sırası; iç içe geçme bağımlılık ( $\beta=-.286)$, Cezalandırıcılık ( $\beta=-.234)$, yüksek standartlar $(\beta=-.217)$, yetersiz özdenetim öz disiplin $(\beta=-.204)$, onay arayıc1lık $(\beta=-.193)$, olumsuzluk karamsarlık $(\beta=-.187)$, sosyal izalasyon güvensizlik $(\beta=-.146)$, terk edilme $(\beta=-.086)$, başarısızlık $(\beta=-.063$, duyguları bastırma $(\beta=-.059$, kusurluluk $(\beta=-.039)$, kendini feda $(\beta=-.037)$, duygusal yoksunluk $((\beta=-.034)$ ve dayanıksızlık $(\beta=-.017)$ şeklindedir.

Regresyon katsayılarının anlamlılığına ilişkin t-testi sonuçlanı incelendiğinde ise; iç içe geçme bağımlılık ( $\mathrm{t}=2.601, \mathrm{p}<.011)$, olumsuzluk karamsarlık $(\mathrm{t}=2.520, \mathrm{p}<.012)$, yüksek standartlar $(\mathrm{t}=$ 2.329, $\mathrm{p}<.022)$, cezalandirıcilık $(\mathrm{t}=2.209, \mathrm{p}<.030)$, yetersiz özdenetim öz disiplin $(\mathrm{t}=1.997, \mathrm{p}<$ $.045)$ ve onay arayıcılık $(\mathrm{t}=1.990, \mathrm{p}<.047)$ şema boyutlarının ÇDMHA puanlarının anlamlı bir yordayıcısı olduğu görülmektedir. Regresyon katsayılarının anlamlıı̆̆ına ilişkin t-testi sonuçlarına göre; sosyal izalasyon güvensizlik, terk edilme, başarısızlık, duyguları bastırma, kusurluluk, kendini feda, duygusal yoksunluk ve dayanıksızlık şema boyutları, ÇDMHA puanlarını anlamlı ölçüde yordamamaktadır. 
Regresyon analizi sonuçlarına göre, şema boyutlarının ÇDMHA'nı yordamasına ilişkin denklem şu şekilde oluşmuştur:

ÇDMHA $=135.61+($ terk edilme x -1.881$)+($ sosyal izalasyon güvensizlik x -3.017$)+($ duygusal yoksunluk x .491) $+($ kusurluluk $\quad$ x.934) + (iç içe geçme bağımlılık x 6.060) + $($ dayanıksızlık $\mathrm{x}-.297)+($ başarısızlık x 1.196) + (yetersiz özdenetim öz disiplin x -4.025) + (onay arayıcıllk x -3.880) $+($ kendini feda $\mathrm{x}-.658)+($ olumsuzluk karamsarlık x -3.127$)+$ (duygular1 bastırma $\mathrm{x}$.915) $+($ cezalandırıcllı x -5.126$)+($ yüksek standartlar x -3.917)

\section{Psikolojik Semptomlar ile Çocukluk Dönemi Mutluluk ve Huzur Anıları (ÇDMHA) Arasındaki İlişkiye Ait Bulgular}

Kısa semptom tarama envanterinin ölçtüğ̈̈̈; anksiyete, depresyon, olumsuz benlik, somatizasyon ve hostilite ile ÇDMHA arasındaki ilişkiye ait bulgular Tablo 7’de gösterilmiştir.

Tablo 7. Psikolojik semptomlar ile ÇDMHA arasındaki ilişkiye ait bulgular

\begin{tabular}{|c|c|c|c|c|c|c|c|c|c|}
\hline & & Ort. & SS & $\mathrm{r}$ & B & $\mathrm{SH}$ & Beta & $\mathrm{t}$ & Sig. \\
\hline (Sabit) & & & & & 99.996 & 2.63 & & 37.995 & .000 \\
\hline Anksiyete & & 0.95 & 0.16 & -.362 & 5.683 & 3.22 & .201 & 1.766 & .080 \\
\hline Depresyon & & 1,36 & 0,14 & -.598 & -4.110 & 2.54 & -.218 & -1.617 & .109 \\
\hline Olumsuz Benlik & & 1,22 & 0,21 & -.639 & -7.984 & 2.07 & -.462 & -3.862 & .000 \\
\hline Somatizasyon & & 1.19 & 0.17 & -.469 & -7.412 & 3.08 & -.253 & -2.411 & .018 \\
\hline Hostilite & & 0.84 & 0.18 & -.296 & 1.143 & 2.32 & .045 & .493 & .623 \\
\hline $\begin{array}{l}\mathrm{R}=.677 \\
\mathrm{~F}=19.274\end{array}$ & $\begin{array}{l}\mathrm{R}^{2}=.458 \\
\mathrm{p}<.000\end{array}$ & Dü & miş $\mathrm{R}$ & 434 & & & & & \\
\hline
\end{tabular}

Araştırma örneklemini oluşturan bireylerin, kısa semptom tarama envanterinden aldıkları puanların aritmetik ortalamaları incelendiğinde, depresyon (1.36), olumsuz benlik (1.22) ve somatizasyon (1.19) en fazla gözlenen semptomlar olduğu, anksiyete (0.95) ve hostilitenin (0.84) göreceli olarak daha az gözlendiği ve bu iki semptomun 1.00 puanlık sınırın altında kaldığı saptanmıştır.

ÇDMHA puanları ile psikolojik semptomlar arasında en yüksek korelasyon, "olumsuz benlik" (r= -.639, p<.000)'de gözlenmiştir. İkinci sırada yüksek korelasyon ise “depresyon” ( $r=-.598, \mathrm{p}<.000)$ boyutunda saptanmıştır. Bununla birlikte ÇDMHA ile beş psikolojik semptom arasındaki korelasyonlar orta ve yüksek düzeyde negatif yönde ve istatistiksel bakımdan anlamlıdır. Bu durum ÇDMHA ile olumsuz benlik, depresyon, somatizasyon, anksiyete ve hostilitenin ilişkili olduğunu, ÇDMHA puanları arttıkça semptomların görülme sıklığının azaldığını, çocukluğunda daha düşük düzeyde mutluluk ve huzur anıları rapor eden katılımcılarda ise semptom puanlarının yükseldiğini göstermesi bakımından önemli bulunmuştur. 
Yapılan regresyon analizinde de psikolojik semptomlar (anksiyete, depresyon, olumsuz benlik, somatizasyon ve hostilite) birlikte, ÇDMHA puanlarıyla aralarında yüksek düzeyde ve anlamlı bir ilişki saptanmıştır. $\left(\mathrm{R}=.677, \mathrm{R}^{2}=.458, \mathrm{p}<0.00\right)$. Beş semptom birlikte, ÇDMHA puanlarına ilişkin toplam varyansın \%46'sını açıklamaktadır. Bu durum, ÇDMHA ile psikolojik semptomlar arasındaki ilişkiyi gösteren bir diğer önemli kanıt olarak değerlendirilmiştir.

Standartdize edilmiş regresyon katsayısına $(\beta)$ göre, yordayıcı değişkenlerin ÇDMHA puanları üzerindeki göreli önem sirası; olumsuz benlik $(\beta=-.462)$, somatizasyon $(\beta=-.253)$, depresyon $(\beta$ $=-.218)$, anksiyete $(\beta=.201)$ ve hostilite $(\beta=-.045)$ şeklindedir. En yüksek Beta değerlerinin olumsuz benlik boyutunda gözlenmesi, ÇDMHA ile en güçlü ilişkinin ve açılama gücünün bu boyuta ait olduğunu göstermektedir. Diğer bir ifade ile, ÇDMHA üzerinde en fazla etkide bulunan değişken, olumsuz benliktir. Regresyon katsayılarının anlamlılı̆̆ına ilişkin t-testi sonuçları da benzer kanıtlar vermiştir. Regresyon katsayılarının anlamlılığını sınamak için uygulanan t testi sonuçlarına göre, beş semptomdan olumsuz benlik $(\mathrm{t}=3.862, \mathrm{p}<.000)$ ve somatizasyonun $(\mathrm{t}=2.411, \mathrm{p}<.018)$, ÇDMHA puanlarının anlamlı bir yordayıcısı olduğu görülmektedir. Elde edilen t değerleri anksiyete, depresyon ve hostilitenin ÇDMHA puanlarını anlamlı yordama özelliği taşımadığını göstermiştir. Regresyon analizi sonuçlarına göre, psikolojik semptomlanın ÇDMHA'nı yordamasına ilişkin denklem şu şekilde oluşmuştur:

ÇDMHA $=99.996+($ anksiyete $\times 5.683)+($ depresyon $x-4.110)+($ olumsuz benlik $x-7.984)+$ (somatizasyon $\mathrm{x}-7.412)+($ hostilite $\mathrm{x} 1.143)$

Kısa semptom tarama envanteri, beş semptoma ilişkin bilgilerin dışında üç global endeks puanı da vermektedir. Rahatsızlık Ciddiyeti Endeksi (RCE), Belirti Toplam Endeksi (BTE) ve Semptom Rahatsızlık Endeksi olarak isimlendirilen üç global endeks, psikolojik semptomların büyüklügünü, ciddiyetini ve bireye verdiği rahatsızlı̆̆n ölçülerini belirlemeyi amaçlamaktadır. Araştırmada bu üç global endeks ile ÇDMHA arasındaki ilişkiler de sınanmıştır. Bu sınamadan elde edilen sonuçlar Tablo 8'de gösterilmiştir.

Tablo 8. KSTE global değerleri ile ÇDMHA arasındaki ilişkiye ait bulgular

\begin{tabular}{|c|c|c|c|c|c|c|c|c|c|c|}
\hline & Ort. & SS & Min. & Max. & $\mathrm{r}$ & B & $\mathrm{SH}$ & Beta & $\mathrm{t}$ & Sig. \\
\hline (Sabit) & & & & & & 99.639 & 8.865 & & 11.240 & .000 \\
\hline RCE & 1,89 & 0.29 & 0 & 4 & -.606 & -17.945 & 7.631 & -.680 & -2.352 & $.020 *$ \\
\hline BTE & 29,43 & 6,28 & 0 & 53 & -.568 & -.080 & .316 & -.051 & -.253 & .801 \\
\hline \multirow[t]{2}{*}{ SRE } & 1,12 & 0.13 & 0 & 4 & -.400 & 4.242 & 4.638 & .151 & .915 & .362 \\
\hline & $\begin{array}{l}\mathrm{R}=.617 \\
\mathrm{~F}=23.718\end{array}$ & $\begin{array}{l}\mathrm{R}^{2} \\
\mathrm{p}<\end{array}$ & & Düzelti & ş $R^{2}=$ & & & & & \\
\hline
\end{tabular}


Rahatsızlık ciddiyeti Endeksi (RCE): bireylerin ruhsal belirtilerinden duymuş oldukları sıkıntıyı ifade eder ve alt ölçeklerin toplamının 53'e bölünmesi yoluyla elde edilir. RCİ sınırları 0 ile 1 arasında olanların psikolojik belirti düzeyleri düşük, 1'den büyük olanların ise yüksek kabul edilmektedir. Araştırmada RCE ortalaması (1.89) olarak hesaplanmıştır. Bu durum katılımcıların psikolojik belirti düzeylerinin yüksek olduğuna işaret etmektedir.

Belirti toplamı Endeksi (BTE), bireylerin kendilerinde algılamıs oldukları ruhsal belirtilerin çeşitliliğini ifade etmektedir. 0 olarak işaretlenen maddeler dışındaki tüm maddelerin (pozitif olan tüm değerler) 1 olarak kabul edilmesi sonucu elde edilen toplam puandır. Bu Endeksin en yüksek puanı 53'tür. Puanların yüksekliği bireydeki psikiyatrik belirtilerden duyulan sıkıntının artışına işaret eder ve ölçeğin en iyi endeksidir. Araştırmada bu değer (29.43) olarak hesaplanmıştır. BTE'nin alabileceği en yüksek değerin 53 olduğu düşünüldüğünde, katılımcıların ortalamanın biraz üzerinde olduğu söylenebilir.

Semptom rahatsizlık Endeksi (SRE), bireylerin kendisinde var olan belirtilerden duydukları sıkıntının ağırlıklı ortalamasını ifade eder. Alt ölçeklerin toplamının belirti toplamına bölünmesi ile elde edilir. SRE'nin yüksekliği, bireyin ruhsal belirtilerden hissettikleri sıkıntının arttığını gösterir. Araştırmada bu değer (1.12) olarak hesaplanmıştır.

Üç global endeks birlikte değerlendirildiğinde katıllmcılarda RCE'nin yüksek olduğu, BTE ve SRE'nin normal sınırlara yakın gözlendiği söylenebilir. Global endeksler ile ÇDMHA puanları arasında hesaplanan korelasyonda da, en yüksek ilişki RCE'de gözlenmiştir ( $r=-.606, p<.000)$. Bununla birlikte BTE ve SRE puanları ile ÇDMHA puanları arasında hesaplanan korelasyon katsayıları da negatif yönde, orta düzeyde anlamlı bulunmuştur.

Yapılan regresyon analizinde de üç global endeks birlikte, ÇDMHA puanlarıyla aralarında yüksek düzeyde ve anlamlı bir ilişki saptanmıştır. $\left(\mathrm{R}=.617, \mathrm{R}^{2}=.380, \mathrm{p}<0.00\right)$. Üç global endeks birlikte, ÇDMHA puanlarına ilişkin toplam varyansın \%38'ini açıklamaktadır. Bu durum, ÇDMHA ile semptom global endekslerinin arasındaki ilişkiyi gösteren önemli bir kanıt olarak değerlendirilmiştir.

Standartdize edilmiş regresyon katsayısına $(\beta)$ göre, global endekslerin ÇDMHA puanları üzerindeki göreli önem sırası; RCE ( $\beta=$-.680), SRE $(\beta=.151)$ ve BTE $(\beta=-.253)$, şeklindedir. En yüksek Beta değerlerinin RCE’de gözlenmesi, ÇDMHA ile en güçlü ilişkinin ve açıklama gücünün bu endekse ait olduğunu göstermektedir. Regresyon katsayılarının anlamlilı̆̆ına ilişkin ttesti sonuçları da bu durumu kanıtlamaktadır. Regresyon katsayılarının anlamlılığını sınamak için uygulanan $\mathrm{t}$ testi sonuçlarına göre, üç global endeksten sadece RCE'nin ( $\mathrm{t}=2.352, \mathrm{p}<.020$ ) ÇDMHA puanlarının anlamlı bir yordayıcısı olduğu görülmektedir. Elde edilen t değerleri BTE ve SRE’nin ÇDMHA puanlarını anlamlı yordama özelliği taşımadığını göstermiştir. Regresyon analizi 
sonuçlarına göre, global endekslerin ÇDMHA'nı yordamasına ilişkin denklem şu şekilde oluşmuştur: ÇDMHA $=99.639+($ RCE x -17.945 $)+($ BTE x -.080 $)+($ SRE x 4.242)

\section{SONUÇ ve TARTIŞMA}

ÇDMHA puanları ile şema alanları arasında en yüksek korelasyonun, "aşırı tetikte olma ketlenme", "zedeleniş sınırlar" ve "zedelenmiş otonomi arasında saptanması şema ve bağlanma kuramının bu açıklamaları ile tutarlılık taşımaktadır. Beş şema alanının birlikte, ÇDMHA puanlarına ilişkin toplam varyansın yarısına yakınını açıklıyor olmasının tespiti de bu açıdan önemlidir. Araştırmada ayrıca; aşırı tetikte olma - ketlenme, zedelenmiş otonomi, kopukluk-reddedilme şema alanlarının, ÇDMHA'nın en güçlü ve anlamlı yordayıcıları olduğunun saptanması da çocukluk dönemi yaşantılarının ileriki yaşlarda oluşan şemaları belirlemedeki etkisini kanıtlamaktadır.

Araştırmada, 5 şema alanının yanında 14 şema boyutu ile ÇDMHA'nın ilişkisinin incelenmesinden de daha ayrıntılı sonuçlara ulaşılmıştır. Bu ayrıntılı analiz sonucunda, ÇDMHA puanları ile şema boyutları arasında en yüksek korelasyon, cezalandırıcılık, olumsuzluk karamsarlık ve yetersiz özdenetim öz disiplin boyutlarında gözlenmiştir.

Bununla birlikte yapılan analizlerde; iç içe geçme bağımlılık, olumsuzluk karamsarlık, yüksek standartlar, cezalandırıcılık, yetersiz özdenetim öz disiplin ve onay arayıcılık şema boyutlarının ÇDMHA puanlarının anlamlı bir yordayıcısı olduğu saptanmıştır.

İç içe geçme-bağımlılık, bireyin başkalarının desteği olmadan varlığını sürdüremeyeceğine dair inancı ve bireysel bir kimlik geliştirememesi olarak açıklanmaktadır (Gay vd., 2013; Rijkeboer ve de Boo, 2010). Olumsuzluk-karamsarlık şeması ise, yaşamın olumlu yönlerini küçümseme; acı, ölüm, kayıp, ihanet, hayal kırıklığı, başarısızlık gibi olumsuz yönlerine fazlaca odaklanma ile karakterize bir durumdur (Boudoukha, Przygodzki-Lionet ve Hautekeete, 2016). Özellikle aşır1 eleştirilme sonucu ortaya çıkan yüksek standartlar şeması, bireyin erişilmesi zor amaçlar belirleyerek başarı ve mükemmellik beklentilerini karşılama amaçlı mücadelesini temsil eder (Nia, Sovani ve Forooshani, 2014). Cezalandırıcılık şeması da bu duruma bağlı olarak gelişir ve bireyin hatalarından dolayı sert bir şekilde cezalandırılması gerektiği inancını oluşturur (Stallard, 2007). Gerek yüksek standartlar gerekse cezalandırıcılık şemaları, bireyin diğer insanlardan onay, kabul ya da ilgi elde etmeye aşırı odaklanması olarak açıklanan onay arayıcılık şema boyutu ile de doğrudan ilişkilidir (Castilho, Pinto-Gouveia, Amaral ve Duarte, 2014). Araştırmada, ÇDMHA'nın anlamlı ve en güçlü yordayıcıları olarak saptanan ve yukarıda özetlenen şema boyutları doğrudan çocukluk dönemi ile ilgili yaşantılara işaret etmektedir. Mutlu ve huzurlu geçen bir çocukluk döneminin bu şemaların oluşmasında önemli bir koruyucu faktör olduğu söylenebilir. Bununla birlikte, çocukluk döneminde bireyin ihtiyaçlarının gereğinden fazla karşılanması, aşırı koruma ve aşırı sevgi, fazla hoşgörü gibi 
tutumların yol açtığı şemalar da söz konusudur. Araştırmada öz denetim-öz disiplin şemasının anlamlı bir yordayıcı olarak saptanması ayrıca önemli bulunmuştur. Bireyin başka insanlardan üstün olduğu, özel hak ve ayrıcalıklara sahip olduğu ve inancına dayanan şişirilmiş benlik duygusu (van Osch, Zeelenberg ve Breugelmans, 2018) bu şema boyutunun en belirgin özelliğidir. Son yıllarda helikopter ebeveynlik olarak tanımlanan tutumların bu şemanın oluşması üzerinde önemli etkileri vardır (McGinley, 2018). Araştırmada elde edilen bu bulgunun bu açıdan ayrı bir önemi olduğu düşünülmektedir.

Araştırmada, şemaların dışında psikolojik semptomlar ile ÇDMHA arasındaki ilişki de incelenmiştir. ÇDMHA puanları ile psikolojik semptomlar arasında en yüksek korelasyon, “olumsuz benlik, somatizasyon ve "depresyon" boyutunda saptanmıştır. Bu durum şemalarla ilgili bulguların psikolojik semptomlarla ilgili bulgularla tutarlılık içinde olduğu şeklinde yorumlanabilir. Psikolojik semptomlara ilişkin bulgular genel olarak değerlendirildiğinde ise, ÇDMHA puanları arttıkça semptomların görülme sıklığının azaldığı, çocukluğunda daha düşük düzeyde mutluluk ve huzur anıları rapor eden katılımcılarda ise semptom puanlarının yükseldiği görülmektedir. Global bir endeks olan Rahatsızlık Ciddiyeti Endeksi ile ÇDMHA arasında anlamlı, negatif ve yüksek bir korelasyonun saptanması da bu durumu destekler nitelikte önemli bir bulgudur. Aynı şekilde, beş semptom birlikte, ÇDMHA puanlarına ilişkin toplam varyansın \%46'sını açıklıyor olması, ÇDMHA ile psikolojik semptomlar arasındaki ilişkiyi gösteren bir diğer önemli kanıt olarak görülebilir. Araştırmada önemli bir bulgu da beş psikolojik semptom arasından olumsuz benliğin ÇDMHA puanlarının en güçlü yordayıcısı olduğudur. Olumsuz benlik puanlarından hesaplanan Standartdize edilmiş regresyon katsayısı, diğer semptomların katsayısından belirgin ölçüde yüksektir. Şemalarla ilgili bulgularda; bireyin başkalarının desteği olmadan varlığını sürdüremeyeceğine dair inancı ve bireysel bir kimlik geliştirememesi olarak açıklanan iç içe geçme-bağımlılık ile; yaşamın olumlu yönlerini küçümseme, olumsuz yönlerine fazlaca odaklanma ile karakterize olumsuzluk-karamsarlık şemasının ÇDMHA ile ilişkisi bakımından ilk iki sırayı alması, psikolojik semptomlara ilişkin elde edilen bu bulguyla tamamen tutarlık içinde olduğunu göstermektedir. Psikolojik semptomların ÇDMHA puanları üzerindeki göreli önem sırasında ikinci sırayı somatizasyonun alması da araştırma sonuçlarının tutarlılığına bir başka kanıt olarak görülebilir.

Olumsuz benlik bireyin kendini başkalarıyla karşılaştırdığında, kişisel yetersizlik ve küçüklük duygularına kapılarak, kişiler arası ilişkilerinde kendisini küçük görmesi, bu ilişkilerde zorluk çekmesi, rahatsılılı hissetmesi gibi olumsuz düşünce ve duygulara sahip olması durumudur (Klemanski Vd., 2017; Jaya, Ascone, Lincoln, 2018). Somatizasyon ise, vücudun kalp, damar, mide, bağırsak, solunum ve diğer sistemlerdeki fonksiyon bozukluklarıyla ilgili sıkıntıları yansıtır. Çözümlenemeyen engelleme veya çatışma sonucu ortaya çıkan işlevsel ve fiziksel bozukluklar 
somatizasyon belirtisi olarak görülmektedir (Bursch, 2010; Garralda, 2011). Bununla birlikte gerek olumsuz benlik gerekse somatizasyon doğrudan anksiyete ve depresyonla bağlantılı belirtilerdir (Irons ve Gilbert, 2005). Araştırmada ÇDMHA'nı yordama gücü açısından depresyonun olumsuz benlik ve somatizasyondan sonra üçüncü sırada yer alması bu açıdan tutarlı bulunmuştur.

Yukarıdaki açıklamalar çerçevesinde, mutsuz ve huzursuz geçen çocukluğun ileriki yaşlarda bu belirtileri ortaya çıkaracağı öngörülebilir. Diğer bir ifade ile, çocukluğa ilişkin mutluluk ve huzur anları fazla olan katılımcılarda olumsuz benlik ve somatizasyon semptomlarına daha az rastlanacağı söylenebilir.

Sonuç olarak yapılan araştırma, çocukluk dönemi mutluluk ve huzur anıları ile bilişsel şemalar ve psikolojik semptomlanın ilişkisini ortaya çıkarmıştır. Özellikle karamsarlık, kötümserlik, cezalandırılma, aşırı eleştirilme ve yüksek standartlar ile karakterize, "aşırı tetikte olma ve ketlenme" şema alanı ÇDMHA ile anlamlı ölçüde ve yüksek düzeyde ilişkilidir. Bu duruma uyumlu olarak, ÇDMHA ile olumsuz benlik ve somatizasyon belirtileri arasında anlamlı ve yüksek korelasyon saptanmıştır.

\section{Sinırlılıklar ve Öneriler}

Araştırma, çocukluk dönemi mutluluk ve huzur anıları ile bilişsel şemalar ve psikolojik semptomlar arasındaki ilişkiyi göstermesine rağmen; katılımcıların çocukluk dönemine ilişkin değerlendirmelerinin ne kadarının anlık psikolojik durumlarından kaynaklanıp kaynaklanmadığını ortaya koymamaktadır. İleride yapılacak araştırmaların, psikolojik semptomlar konusunda klinik teşhis konmuş bireyler üzerinde yapılması önerilir. Bununla birlikte araştırma verileri 18-24 yaş grubundan ve üniversite öğrencilerinden elde edilmiştir. Günümüzde ergenlik döneminin yaş sınırlarının genişliği dikkate alındığında, araştırmanın çalışma grubunun ergenler olduğu söylenebilir. Bu durum ortaya çıkan semptomların, katılımcıların gelişim dönemlerinden etkilenmiş olabileceğini akla getirmektedir. Yapılacak benzer çalışmaların farklı yaş grupları üzerinde ve önemli demografik değişkenleri de kapsayacak nitelikte olması önerilmektedir.

Özellikle uyumsuz bilişsel şemaların yerleşik hale geldikten sonra oldukça kalıcı ve değiştirilmesi zor olduğundan dolayı, ebeveynlere yönelik olarak gerçekleştirilebilecek ebeveynlik eğitimlerinde bu konuya yer verilesi ve bilinçlenmenin sağlanması önleyici bir müdahale olarak önerilmektedir. Uyumsuz şemalarının daha erken dönemde belirlenip, bu şemalara ilişkin çeşitli yöntemlerin kullanılmasını konusunda okul psikolojik danışmanlarına hizmet içi eğitim verilmesi de psikolojik açıdan sağlıklı bireylerin yetiştirilmesine hizmet edecektir. 


\section{KAYNAKÇA}

Acevedo, A. (2018). A Personalistic Appraisal of Maslow's Needs Theory of Motivation: From "Humanistic" Psychology to Integral Humanism. Journal of Business Ethics, 148(4), 741-763. https://doi.org/10.1007/s10551-015-2970-0

Akın, A., Uysal, R. ve Çitemel, N. (2013). Çocukluk dönemi mutluluk/huzur anıları ölçeğinin Türkçe formunun geçerlik ve güvenirlik çalışması, Uludağ Üniversitesi Eğitim Fakültesi Dergisi, 26 (1), 71-80.

Allan, W.D., Kashani, J.H. ve Reid, J.C. (1998). Parental Hostility: Impact on the Family. Child Psychiatry ve Human Development, 28(3),169-178. https://doi.org/10.1023/A:1022833810248

Alto, M., Hveley, E., Rogosch, F., Cicchetti, D. ve Toth, S. (2018). Maternal relationship quality ve peer social acceptance as mediators between child maltreatment ve adolescent depressive symptoms: Gender differences, Journal of Adolescence, 63, 19-28, https://doi.org/10.1016/j.adolescence.2017.12.004

Bach, B., Lockwood, G. ve Young, J.E. (2018) A new look at the schema therapy model: organization ve role of early maladaptive schemas, Cognitive Behaviour Therapy, Journal Cognitive Behaviour Therapy, 47(4), 328-349. https://doi.org/10.1080/16506073.2017.1410566

Baldwin, M, W. ve Dveeneau, S. D. (2005). Understveing ve modifying the relational schemas underlying insecurity. In M. W. Baldwin (Ed.), Interpersonal cognition (pp. 33-61). New York: Guilford Press.

Borch-Jacobsen, M.ve Shamdasani, S. (2012). The Freud Files: An Inquiry into the History of Psychoanalysis. Cambridge: Cambridge University Press. p. 43. ISBN 978-0-521-72978-9.

Boudoukha, A. H., Przygodzki-Lionet, N. ve Hautekeete, M. (2016). Traumatic events ve early maladaptive schemas (EMS): Prison guard psychological vulnerability. Appliquée/European Review of Applied Psychology, 66(4), 181-187. https://doi.org/10.1016/j.erap.2011.05.004

Brewin, C. R., Verews, B. ve Gotlib, I. H. (1993). Psychopathology ve early experiences: A reappraisal of retrospective reports. Psychological Bulletin, 113, 82-98. doi:10.1037/00332909.113.1.82

Bursch, B. (2010). Somatization Disorder. In The Corsini Encyclopedia of Psychology (eds I. B. Weiner ve W. E. Craighead). John Wiley ve Sons, Inc. Doi:10.1002/9780470479216.corpsy0927

Burton, T., Farley, D. ve Rhea, A. (2009). Stress- induced somatization in spouses of deployed ve nondeployed servicemen. Journal of the American Academy of Nurse Practitioners, 21(6), 332-339 doi:10.1111/j.1745-7599.2009.00411.x

Canavarro, M. C. ve Pereira, A. I. (2007). Children's perception of their parents' rearing style: The Portuguese version of EMBU-C. Revista Iberoamericana de Diagnostico y Evaluacion, 2 (24), 193210. 
Caprara, G. V., Paciello, M., Gerbino, M. ve Cugini, C. (2007), Individual differences conducive to aggression ve violence: trajectories ve correlates of irritability ve hostile rumination through adolescence. Aggr. Behav., 33(4), 359-374. doi:10.1002/ab.20192

Castilho, P., Pinto- Gouveia, J., Amaral, V. ve Duarte, J. (2014), Recall of Threat ve Submissiveness in Childhood ve Psychopathology: The Mediator Effect of Self- Criticism. Clin. Psychol. Psychother., 21, 73-81. doi:10.1002/cpp.1821

Cunha, M., Martinho, M. I., Xavier, A. M. e Espirito-Santo, H. (2013). Early memories of positive emotions ve its relationships to attachment styles, self-compassion ve psychopathology in adolescence. European Psychiatry, 28(Supplement 1), 1. https://doi.org/10.1016/S09249338(13)76444-7

Cunha, M., Ferreira, C., Duarte, C., Andrade, D., Marta-Simões, J. ve Pinto-Gouveia, J. (2017). Assessing positive emotional memories with peers: The Early Memories of Warmth ve Safeness with Peers Scale for adolescents, Journal of Adolescence, 54, 73-81, https://doi.org/10.1016/j.adolescence.2016.11.010

Derogatis, L.R. (1992). SCL-90-R: Administration, Scoring ve Procedures Manual-II, for the R (Revised) Version ve Other Instruments of the Psychopathology Rating Scale Series. 2nd Edition, Clinical Psychometric Research, Inc., Towson.

Dijk, A., Poorthuis, A. M., Thomaes, S. ve Castro, B. O. (2018). Does Parent-Child Discussion of Peer Provocations Reduce Young Children's Hostile Attributional Bias? Child Dev, 89(5), 1908-1920. Doi:10.1111/cdev.13087

Ferreira, C., Cunha, M., Marta- Simões, J., Duarte, C., Matos, M. ve Pinto- Gouveia, J. (2018). Development of a measure for the assessment of peer- related positive emotional memories. Psychol Psychother Theory Res Pract, 91(1), 79-94. https://doi.org/10.1111/papt.12146

Fishbain, D. A., Lewis, J. E., Gao, J., Cole, B. ve Steele Rosomoff, R. (2009). Is Chronic Pain Associated With Somatization/Hypochondriasis? An Evidence - Based Structured Review. Pain Practice, 9(6), 449-467. doi:10.1111/j.1533-2500.2009.00309.x

Galhardo, A., Pinto-Gouveia, J., Cunha, M. ve Matos, M. (2011). The impact of shame ve selfjudgment on psychopathology in infertile patients. Hum Reprod., 26(9), 2408-2414. Doi: 10.1093/humrep/der209

Garralda, E. (2011). Somatization ve Somatoform Disorders. In Child Psychology ve Psychiatry (eds D. Skuse, H. Bruce, L. Dowdney ve D. Mrazek). pp. 147-152, John Wiley ve Sons, Ltd. Doi:10.1002/9781119993971.ch24

Gay, L. E., Harding, H. G., Jackson, J. L., Burns, E. E ve Baker, B. D. (2013). Attachment Style ve Early Maladaptive Schemas as Mediators of the Relationship between Childhood Emotional Abuse ve Intimate Partner Violence, Journal of Aggression, Maltreatment ve Trauma, 22(4), 408-424, https://doi.org/10.1080/10926771.2013.775982

Ghorbani, N., Pourhosein, R. ve Ghobadi, S. A. (2018). Self-compassion, mental health ve work ethics: mediating role of self-compassion in the correlation between work stress ve mental 
health. Middle East Journal of Family Medicine, 16(1), 113-120. https://doi.org/10.5742/MEWFM.2018.93209

Gilbert, P. ve Irons, C. (2009). Shame, self-criticism ve self-compassion in adolescence. In N Allen (Ed.), Psychopathology in Adolescence. Cambridge: Cambridge University Press.

Gledhill, J. ve Hodes, M. (2011). Depression ve Suicidal Behaviour in Children ve Adolescents. In Child Psychology ve Psychiatry (eds D. Skuse, H. Bruce, L. Dowdney ve D. Mrazek). John Wiley ve Sons, Ltd. pp. 186-193. doi:10.1002/9781119993971.ch30

Hollve, A. K., Mitchell, G. A., Steele, A., Bunting, J. ve Harrison, D. W. (2018). Hostility ve cognitive control: Evidence of increased cardiovascular reactivity as a function of exposure to affective stress using a dichotic listening paradigm, International Journal of Psychophysiology, 131, 57-66. https://doi.org/10.1016/j.ijpsycho.2017.09.002

Irons, C. ve Gilbert, P. (2005). Evolved mechanisms in adolescent anxiety ve depressionsymptoms: the role of the attachment ve social rank systems. Journal of Adolescence 28, 325-341. https://doi.org/10.1016/j.adolescence.2004.07.004

Jaya, E. S., Ascone, L. ve Lincoln, T. M. (2018). A longitudinal mediation analysis of the effect of negative-self-schemas on positive symptoms via negative affect. Psychological Medicine, 48(8), 1299-1307. https://doi.org/10.1017/S003329171700277X

Jones-Rincon, A. ve Howard, K. J. (2018). Anxiety in the workplace: A comprehensive occupational health evaluation of anxiety disorder in public school teachers. $J$ Appl Behav Res. Erken görünüm: e12133. https://doi.org/10.1111/jabr.12133

Karen, A. (2018). Integrative Review of the Relationship Between Mindfulness-Based Parenting Interventions ve Depression Symptoms in Parents. Journal of Obstetric, Gynecologic ve Neonatal Nursing, 47(2), 184-190. https://doi.org/10.1016/j.jogn.2017.11.013

Kaya T., Tutarel K. ve Boysan, M. (2015). Relationships between Childhood Traumatic Experiences, Early Maladaptive Schemas ve Interpersonal Styles. Noro Psikiyatr Ars., 52(3), 226-232. doi: 10.5152/npa.2015.7118. Epub 2015 Jul 7.

Klemanski, D.H., Curtiss, J., McLaughlin, K.A. Nolen-Hoeksema, S. (2017). Emotion Regulation ve the Transdiagnostic Role of Repetitive Negative Thinking in Adolescents with Social Anxiety ve Depression. Cognitive Therapy ve Research, 41(2), 206-219. https://doi.org/10.1007/s10608-016-9817-6

Long, E. E., Young, J. F. ve Hankin, B. L. (2018). Temporal dynamics ve longitudinal cooccurrence of depression ve different anxiety syndromes in youth: Evidence for reciprocal patterns in a 3-year prospective study. Journal of Affective Disorders, 234, 20-27. https://doi.org/10.1016/j.jad.2018.02.074

Martin, R. ve Young, J. (2010). Schema therapy. In K. S. Dobson (Ed.), Handbook of cognitivebehavioral therapies (pp. 317-346). New York, NY, US: Guilford Press.

Matos, M., Pinto-Gouveia, J. ve Duarte, C. (2013). Internalizing Early Memories of Shame ve Lack of Safeness ve Warmth: The Mediating Role of Shame on Depression. Behavioural ve Cognitive Psychotherapy, 41(4), 479-493. https://doi.org/10.1017/S1352465812001099 
Mc Ginley, M. (2018) Can Hovering Hinder Helping? Examining the Joint Effects of Helicopter Parenting ve Attachment on Prosocial Behaviors ve Empathy in Emerging Adults, The Journal of Genetic Psychology, $179(2), \quad 102-115$. https://doi.org/10.1080/00221325.2018.1438985

Mikulincer, M. ve Shaver, P. R. (2008). Adult attachment ve affect regulation. In J. Cassidy ve P. R. Shaver (Eds.), Hvebook of attachment: Theory, research ve clinical applications (pp. 503-531). New York, NY, US: Guilford Press.

Nia, K. M., Sovani, A.ve Forooshani, S. G. R. (2014). Exploring Correlation Between Perceived Parenting Styles, Early Maladaptive Schemas ve Depression Among Women With Depressive Symptoms in Iran ve India- Role of Early Maladaptive Schemas as Mediators ve Moderatos. Iranian Red Crescent Medical Journal, 16(12), e17492. http://doi.org/10.5812/ircmj.17492

O’Dougherty Wright, M., Crawford, E. ve Del Castillo, D. (2009). Childhood emotional maltreatment ve later psychological distress among college students: The mediating role of maladaptive schemas. Child Abuse ve Neglect, 33(1), 59-68. https://doi.org/10.1016/j.chiabu.2008.12.007

Quirk, S.W., Wier, D., Martin, S.M. ve Christian, A. (2015) The Influence of Parental Rejection on the Development of Maladaptive Schemas, Rumination ve Motivations for Self-Injury. Journal of Psychopathology ve Behavioral Assessment, 37(2), 283-295. https://doi.org/10.1007/s10862-014-9453-y

Pellerone, M., Craparo, G. ve Tornabuoni, Y. (2016). Relationship between Parenting ve Cognitive Schemas in a Group of Male Adult Offenders, Front. Psychol., 7, 1-11. https://doi.org/10.3389/fpsyg.2016.00302

Preston S. D. (2013). The origins of altruism in offspring care. Psychol. Bull. 139, 1305-1341. https://doi.org/10.1037/a0031755

Richter, A., Gilbert, P. ve Mc Ewan, K. (2009). Development of an early memories of warmth ve safeness scale ve its relationship to psychopathology. Psychology ve Psychotherapy: Theory, Research ve Practice, 82, 171-184.

Richter, G.ve Mc Ewan, K. (2010). Development of an early memories of warmth ve safeness scale ve its relationship to psychopathology, Psychology ve Psychotherapy: Theory, Research ve Practice, 82(2), 171-184. https://doi.org/10.1348/147608308X395213

Rijkeboer, M. M. ve de Boo, G. M. (2010). Early maladaptive schemas in children: Development ve validation of the schema inventory for children. Journal of Behavior Therapy ve Experimental Psychiatry, 41 (2), 102-109. https://doi.org/10.1016/j.jbtep.2009.11.001

Rubin, D. C. (2000). The distribution of early childhood memories, Memory, 8(4). https://doi.org/10.1080/096582100406810

Savaşır, I. Şahin, N.H. (1997). Bilişsel Davranışıı Terapilerde Değerlendirme: Sık Kullanılan Ölçekler. Ankara: Türk Psikologlar Derneği Yayınları. 
Scaramella, L.V. and Leve, L. D. (2004). Clarifying Parent-Child Reciprocities During Early Childhood: The Early Childhood Coercion Model, Clinical Child ve Family Psychology, 7(2), 89-107. https://doi.org/10.1023/B:CCFP.0000030287.13160.a3

Schachter, E. P. (2018). Intergenerational, Unconscious ve Embodied: Three Underdeveloped Aspects of Erikson's Theory of Identity, Identity, Erken görünüm. https://doi.org/10.1080/15283488.2018.1523731

Schmidt, N. B., Joiner, T. E., Young, J. E. ve Telch, M. J. (1995). The schema questionnaire: Investigation of Psychometric Properties ve the Hierarchical Structure of a Measure of Maladaptive Schemas. Cognitive Therapy ve Research,19(3), 295-321. https://doi.org/10.1007/BF02230402

Schmoeger, M., Deckert, M., Wagner, P., Sirsch, U. Ve Willinger, U. (2018). Maternal bonding behavior, adult intimate relationship ve quality of life. Neuropsychiatrie, 32(1), 26-32. https://doi.org/10.1007/s40211-017-0258-6

Schore, A. N. (2001). Effects of a Secure Attachment Relationship on Right Brain Development, Affect Regulation ve Infant Mental Health. Infant Mental Health Journal, 22(1-2). 7-66. https://doi.org/10.1002/1097-0355(200101/04)22:1<7::AID-IMHJ2>3.0.CO;2-N

Shefer, N., Carmeli, A. ve Cohen- Meitar, R. (2018). Bringing Carl Rogers Back In: Exploring the Power of Positive Regard at Work. British Academy of Management, 29(1), 63-81. https://doi.org/10.1111/1467-8551.12247

Shettar, M., Kakunje, A., Karkal, R., Mendonsa, R.D., Kini, G., and Mohan Chveran, V. V. (2018). Suicidality in somatization ve undifferentiated somatoform disorders: A hospital-based study. Arch Med Health Sci, 6(1), 36-39. http://www.amhsjournal.org/text.asp?2018/6/1/36/234103

Soygüt, G., Karaosmanoğlu, A. ve Çakır, Z. (2009). Erken dönem uyumsuz şemaların değerlendirilmesi: Young Şema Ölçeği Kısa Form-3'ün psikometrik özelliklerine ilişkin bir inceleme. Türk Psikiyatri Dergisi, 20(1), 75- 84.

Stallard, P. (2007). Early maladaptive schemas in children: Stability ve differences between a community ve a clinic referred sample. Clinical Psychology ve Psychotherapy, 14(1), 10-18. https://doi.org/10.1002/cpp.511

Şahin, N. H., Durak B, A. ve Uğurtaş, S. (2002). Kısa semptom envanteri (KSE): ergenler için kullanımının geçerlilik, güvenilirlik ve faktör yapısı. Türk Psikiyatri Dergisi, 13(2), 125-135.

Tahirović, S. ve Jusić, M. (2016). Earliest Memories, Positive Emotional Memories of Warmth ve Safeness ve Attachment Style in Adolescent, Epiphany. Journal of Transdisciplinary Studies, 9(1), 149-160. https://doi.org/10.21533/epiphany.v9i1.211

Vagos, P., Ribeiro da Silva, D., Brazão, N., Rijo, D., ve Gilbert, P. (2017). The Early Memories of Warmth ve Safeness Scale for adolescents: Cross- Sample Validation of the Complete ve Brief Versions. Clin. Psychol. Psychother, 24(3), 793-804. https://doi.org/10.1002/cpp.2059 
Vallance, A. ve Garralda, E. (2011). Anxiety Disorders in Children ve Adolescents. In Child Psychology ve Psychiatry (eds D. Skuse, H. Bruce, L. Dowdney ve D. Mrazek). pp. 169-174. doi:10.1002/9781119993971.ch27

Vveell, D. L., Belsky, J., Burchinal, M., Steinberg, L., Vveergrift, N. (2010), Do Effects of Early Child Care Extend to Age 15 Years? Results From the NICHD Study of Early Child Care ve Youth Development. Child Development, 81(3), 737-756. https://doi.org/10.1111/j.14678624.2010.01431.x

van Osch, Y., Zeelenberg, M. ve Breugelmans, S. M. (2018). The self ve others in the experience of pride, Cognition ve Emotion, 32(2), 404-413. https://doi.org/10.1080/02699931.2017.1290586

WHO, War Trauma Foundation ve World Vision International. (2011). Psychological first aid: guide for field workers. Geneva: World Health Organization. http://www.who.int/iris/hvele/10665/44615

Widom, C. S., Czaja, S. J., Kozakowski, S. S. ve Chauhan, P. (2018). Does adult attachment style mediate the relationship between childhood maltreatment ve mental ve physical health outcomes? Child Abuse ve Neglect, 76, 533-545. https://doi.org/10.1016/j.chiabu.2017.05.002

Young, J. E. (1990). Cognitive Therapy for Personality Disorders: A schema-focused approach. Sarasota, FL: Professional Resource Exchange. (pp. 67-69). https://trove.nla.gov.au/work/27900631

Young, J. E., Klosko, J. S. ve Weishaar, M. E. (2003). Schema therapy: A practitioner's guide. (pp. 4853). New York: The Guilford Press.

Young, J. E. ve Brown, G. (1994). Young Schema-Questionnaire (2nd ed.). In J. E. Young, Cognitive therapy for personality disorders: A schema-focused approach (Rev. ed., pp. 63-76). Sarasota, FL: Professional Resource Press. 